Жарнікова Валерія Владиславівна, аспірант кафедри обліку та оподаткування, Київський національний торговельно-економічний університет, Київ, Україна

\title{
ОБЛІК РОЗРАХУНКІВ $З$ ПОКУПЦЯМИ: СИСТЕМАТИЗАЦІЯ ПОГЛЯДІВ ТА ПЕРСПЕКТИВИ ДОСЛІДЖЕНЬ
}

\begin{abstract}
Анотація. У статті досліджено наукову та періодичну літературу з питання обліку розрахунків з покупиями за останні двадиять років. Проаналізовано сутність поняття «розрахунки» та надано характеристику форм прояву розрахунків з покупиями за різними аспектами, в тому числі: економічному, бухгалтерському, податковому, банківському та юридичному. В системі розрахунків деталізовано форми прояву розрахунків з покупиями по перерахованим вище критеріям. Визначено, що формою прояву економічного аспекту розрахунків з покупиями $\epsilon$ прибуток від продажу товарів і збиток по сумнівних боргах, бухгалтерського аспекту - виручка від реалізачії та дебіторська заборгованість, податкового аспекту - податковий кредит і податок на прибуток, банківського аспекту - кредитування та банківські гарантії, юридичного аспекту — договори купівлі-продажу та агентські угоди. Розглянуто різні підходи до проблематики останніх публікацій з тематики розрахунків з покупцями та визначено коло питань, що досліджені достатньо широко та частково. Проведено грунтовний аналіз досліджень та здійснено систематизацію поглядів вчених іпрактиків з питань обліку розрахунків з покупиями. Розглянуті вище наукові та практичні публікації розподілено по галузевій спрямованості дослідження на три групи: оптова торгівля, роздрібна торгівля, інші галузі. За сферами дослідження публікації систематизовано також на три групи: дебіторська заборгованість, розрахунки з покупиями, системи лояльності.

Рекомендації щодо вдосконалення обліку розрахунків з покупиями, викладені в досліджуваних джерелах класифіковані по семи напрямках, в тому числі: класифікачія, оцінка в бухгалтерському обліку, документальне оформлення та відображення у фінансовій звітності, відображення на рахунках бухгалтерського обліку, показники оборотності та їх аналіз, впровадження інформаційних технологій та Інтернет-технологій, а також оподаткування. На базі проведених досліджень проблемних питань бухгалтерського обліку розрахунків з покупчями в торгівлі окреслено п'ять напрямків, що вимагають подальщих наукових досліджень.
\end{abstract}

Ключові слова: розрахунки; систематизація; розрахунки з покупчями; торгівля; програми лояльності.

\section{ВСТУП}

Постановка проблеми. Процес продажу товарів та розрахунків з покупцями за передані товарно-матеріальні цінності являється одним 3 найбільш актуальних, оскільки розрахунки між підприємствами, організаціями та кінцевими споживачами $є$ необхідною ланкою розширеного відтворення, від якої залежить не тільки кінцеві результати підприємств та організацій, ix фінансовий стан, а й економічне зростання країни в цілому.

Інтенсивний перехід підприємств та організацій на нові економічні відносини, викликає необхідність активніше використовувати бухгалтерський облік для удосконалення операційної діяльності. Сучасні економічні відносини 
які склалися, об'єктивно вимагають оновлення теоретико-методологічних засад бухгалтерського обліку та максимального наближення до міжнародних стандартів, особливо в сфері оптової та роздрібної торгівлі, де чіткий облік розрахунків з покупцями є необхідним елементом ефективного управління.

Постійно зростаючі потреби ефективного управління розрахунками з покупцями вимагають відповідних змін в системі обліку, формах, видах розрахунків, методах управління та впливу на дебіторську заборгованість. Процеси автоматизації, розвиток Інтернет - технологій потребують адаптації та уточнення обліку розрахунків з покупцями до сучасних потреб. Перелічені фактори впливають на сферу обліку розрахунків з покупцями та ставлять питання систематизації існуючих поглядів з окресленої тематики та визначення перспективних напрямків досліджень обліку розрахунків з покупцями.

Аналіз останніх досліджень i публікацій. Дослідженням загального поняття «розрахунки» займалися як вітчизняні так і зарубіжні вчені-економісти, зокрема: П.С. Безруких, В.М. Пархоменко, О.П. Подцерковний, І.О. Власова, М.М. Чорнобривець, Б. Райан, С. Бутчер та інші. Разом з цим, тематика обліку розрахунків з покупцями та замовниками знайшли висвітлення у працях таких українських науковців, як Бутинець Ф.Ф., Булкат Г., Нашкерська Г., Сливка Я.В., Білик М.Д., Кужель О., Левкина Л., Лишиленко О.В., Даньків Й.Я., Пушкар М.С., Сопко В.В., Хом'як Р.Л., Чебанова Н.В. та іншими. Проте ряд питань досі залишаються недостатньо вивченими, що зумовило актуальність даного дослідження.

Мета статті. Метою написання статті $€$ вивчення проблемних питань щодо обліку розрахунків з покупцями та замовниками на сучасному етапі розвитку економіки України, систематизація наукових поглядів з окресленої тематики, а також визначення подальших напрямків дослідження.

\section{РЕЗУЛЬТАТИ ДОСЛІДЖЕННЯ}

Розвиток ринкових взаємовідносин та орієнтація на міжнародні стандарти бухгалтерського обліку вимагає прозорості розрахунків, в межах відповідної системи платежів. Як основний інструмент регулювання ринкових взаємовідносин розрахунки мають важливе значення та потребують грунтовного дослідження та уточнення поняття «розрахунки» 3 різних точок зору: економічної, бухгалтерської, податкової, банківської, юридичної.
Вивчення й аналіз поняття «розрахунки» у фаховій літературі показав, що на практиці переважає трактування розрахунку, як підрахунку чого-небудь чи здійснення платежів за що-небудь чи виконання грошових зобов'язань [1], або, як документу складеного на основі розрахунку [2]. В науковій літературі досліджуване поняття розглядається, як грошові взаємовідносини, що виникають між організаціями по товарних і нетоварних операціях [3], як зобов'язання покупця оплатити у встановлений термін вартість заборгованостей, після виконання договірних зобов'язань [4].

Відмінність у трактуваннях свідчить про поєднання в досліджуваному понятті змісту платежу, взаємовідносин та зобов'язань, що в свою чергу об'єднує юридичну та економічну суть поняття. Розповсюджене розуміння поняття «розрахунку», як платежу, відповідно до нарахованих зобов'язань, відкидає випадки часткових розрахунків, здійснення платежів без виникнення зобов'язань, або виникнення зобов'язань, що викликані трудовими, адміністративними, податковими, митними, фінансовими відносинами, що потребує більш детальнішого розгляду поняття «розрахунки» з економічної точки зору [5].

Відповідно до концепції зобов'язань Б. Райана, слід розмежувати зв'язки між поняттями «зобов'язання», «розрахунки» та «заборгованість». Зобов'язання мають масштабний характер і проникають в усі сфери діяльності підприємства. Вони виникають 3 моменту прийняття будь-якого рішення, але не кожне зобов'язання $є$ дійсним. В разі прийняття рішення про практичну реалізацію зобов'язання, яке передбачає обмін ресурсами, та набуття ним юридичного оформлення, його можна вважати фінансовим зобов'язанням. Виконання фінансового зобов'язання відбувається через систему розрахунків, які виникають та припиняються в момент руху тих чи інших ресурсів (або грошових коштів, або товарів, робіт, послуг). Стан розрахунків в будь-який момент їх існування характеризується дебіторською та кредиторською заборгованістю для кожного учасника [6].

За цих умов в бухгалтерському обліку мають відображатися не зобов'язання як такі, а саме розрахунки за фінансовими зобов'язаннями, оскільки вони виникають за належним чином юридично оформленою угодою та з моменту іiі практичного виконання: $з$ дати появи заборгованості до дати їі погашення .

В своїй книзі М. П. Березіна наводить перелік основних елементів структури розрахункових взаємовідносин, в процесі економічної діяльності [7]: 
- суб'єкти (учасники): банки та інші установи, що здійснюють міжбанківські розрахунки; населення; підприємства;

- об’єкт розрахунків: товари та послуги; внески до бюджету;

- місце проведення розрахунків: внутрішньодержавні; міжнародні;

- види платежу: строкові; дострокові; планові; відстрочені; прострочені;

- системи переказу грошей: поштовий зв'язок; спеціальні служби зв'язку; кур'єри; фельд’єгерська служба; служба інкасації; електронний зв'язок; міжнародні комунікації SWIFT;

- форма розрахунку: перекази; відкритий рахунок, акредитиви, інкасо;

- спосіб погашення боргового зобов'язання: валовий спосіб, кліринг;

- платіжні інструменти: кредитових переказів (платіжні вимоги-доручення, платіжні вимоги); дебетових переказів (вексель, чек, інкасове-доручення); проміжні інструменти (акредитиви, пластикові картки); носії (паперові, пластикові, електронні);

- наявність гарантії платежу: гарантовані платежі (векселями, чеками, акредитивами); негарантовані (платіжними дорученнями, платіжними вимогами-дорученнями, платіжними вимогами);

- наявність посередників: прямі, транзитні;

- ризики: правовий ризик; ризик неліквідності; кредитний; системний; операційний; ризик шахрайства;

- величина платежів: оптові та роздрібні.

Дослідження поняття «розрахунків» грунтовно здійснено в дисертації I.О. Власової «Облік розрахунків з дебіторами та кредиторами». Автор зазначає, що у бухгалтерському обліку розрахункові операції є об'єктом обліку, по-перше, як динамічний процес (проведення платежу до, одночасно чи після одержання товарів, робіт, послуг) i, по-друге, як статичний стан, тобто заборгованість між суб'єктами розрахунків. За думкою І. О. Власової розрахунки включають в себе одночасно двосторонній рух і грошових коштів, і товарів (робіт та послуг), тому відповідно документи при проведенні розрахункових операцій поділяються на дві складові: фінансові та товарно-розрахункові [8].

Трактування поняття "розрахунки», 3 позиції системи взаємовідносин між юридичними i фізичними особами, передбачає виникнення розрахунків у момент практичного виконання юридично оформлених фінансових зобов'язань при здійсненні товарних і нетоварних операцій.

Розрахунки між юридичними і фізичними особами, передбачають виникнення зобов'язань по сплаті податків. Згідно з п. 44.1 ст. 44 цього Податкового Кодексу для цілей оподаткування платники податків зобов'язані вести облік доходів, витрат та інших показників, пов'язаних із визначенням об'єктів оподаткування та/або податкових зобов'язань, на підставі первинних документів, регістрів бухгалтерського обліку, фінансової звітності, інших документів, пов'язаних з обчисленням і сплатою податків і зборів, ведення яких передбачено законодавством. [9]

Об'єктом розрахунків за податками згідно 3 податковим законодавством в цілому має виступати база та/або об'єкт оподаткування і податкові зобов'язання платника податку. Предмет, який обкладається податком, називається об'єктом оподаткування.

Об'єктами оподаткування i об'єктами, пов'язаними з оподаткуванням $є$ майно та дії, у зв'язку з якими у платника податків виникають обов'язки щодо сплати податків та зборів. Такі об’єкти за кожним видом податку та збору визнаються згідно з відповідним розділом Податкового кодексу.

Розрахунки за податками входять до складу джерел утворення господарських засобів та формують поточні зобов'язання, оскільки передбачається їх погашення протягом одного операційного циклу чи протягом дванадцяти місяців від дати складання балансу. Податковий облік нерозривно пов'язаний з бухгалтерським обліком.

Так, Ф. Ф. Бутинець, під податковим обліком розглядає систему бухгалтерського обліку, яка на основі затверджених державою правил виконує функції нарахування та сплати податків і надходження інформації про це відповідним державним органам [10]. Разом 3 цим, В. Сердюк зазначає, що податковий облік - система накопичення інформації, необхідної для розрахунку податків і контролю за їхньою сплатою [11]. За думкою О. Малишкіна, податковий облік - підсистема інформації платника податку, яка здійснює виявлення, реєстрацію, розрахунок та узагальнення економічної інформації щодо бази оподаткування та суми податку відповідно до податкового законодавства для надання відповідним державним органам декларацій (розрахунків) з метою сплати податкового зобов'язання або повернення податку з бюджету [12].

В банківській сфері поняття «розрахунків» розглядається, як система розрахунків, що являє собою платіжну організацію, учасники системи розрахунків та взаємовідносини, що виникають між ними щодо проведення розрахунків за валютні цінності та фінансові інструменти. 
Основною 3 функцій банків є зберігання коштів і проведення грошових розрахунків готівкові i безготівкові, та посередницька діяльність у платежах. Для здійснення платежу банками застосовується певний інструментарій у формі розрахункових операцій. В своїй монографії «Методологічні основи формування системи фінансового менеджменту банку» I.I. Д’яконова зазначає, що розрахунковою банківською операцією $є$ певна правова дія, що складається 3 комплексу техніко-юридичних засобів, яка спрямована на здійснення платежу з метою повного або часткового погашення грошового зобов'язання [13].

У правовій категорії поняття «розрахунки» переходить у термін «розрахункові правовідносини», що деталізує коло учасників, їх права і обов'язки. Розрахункові правовідносини здійснюються між усіма учасниками і мають на меті досягнення виконання окремих зобов'язань: по-перше, для боржника сплатити зобов'язання; по-друге, для кредитора-отримати кошти своєчасно і в повному обсязі; по-третє для банку-забезпечити переказ грошових коштів.

Розрахункові правовідносини виникають внаслідок здійснення платником дій, що спрямовані на проведення платежу одержувачу, при цьому розрахунковим правовідносинам притаманні такі особливості:

- об'єктом виступають гроші, як засіб платежу, тобто ці правовідносини мають грошовий характер;

- розрахунки здійснюються при наявності коштів на рахунку платника або наявність кредитних коштів;

- обов’язкова участь банківської установи, платника і одержувача коштів;

- виступають у формі зобов'язань, які виконуються шляхом реалізації взаємопов'язаних дій.

Вищенаведені елементи є складовими договору, процедура розрахунків в якому відокремлюється від основного змісту операції і переходять в грошові відносини, які формують поняття «розрахунки» описані в дисертації Подцерковного О.П. «Організаційно-правові основи розрахункових відносин у господарському комплексі» [14].

Спосіб розрахунку залежить від статусу суб'єктів правовідносин та підстав для платежу. Розрахунки у більшості випадків здійснюються у безготівковому порядку, відповідно Цивільного кодексу України, а основні форми приводяться згідно Інструкції № 22 про безготівкові розрахунки в Україні в національній валюті, затвердженою Постановою Правління НБУ від 21.01.2004, які можна обрати для розрахунку.
Регулювання розрахунковими правовідносинами здійснюється Цивільним кодексом України, Господарським кодексом України, законами України «Про Національний банк України», «Про банки і банківську діяльність», «Про платіжні системи та перекази коштів в Україні», «Про застосування реєстраторів розрахункових операцій у сфері торгівлі, громадського харчування та послуг».

В підручнику «Гроші як об’єкт цивільних правовідносин» колективу авторів, виданим під керівництвом О.В. Дзера розглядається поняття «розрахунки», як односторонній правочин, спрямований на повне або часткове погашення грошових зобов’язань [15]. Також під розрахунком розуміють правомірні дії боржника, спрямовані на погашення грошового зобов'язання, припинення або заміни (передання відступного, новація, прощання боргу).

3 юридичної точки зору, автори розглядають розрахунок, як правову дію, що $є$ елементом зобов'язання однієї із сторін договору, а також може бути елементом одностороннього правочину (дія банку-емітента зі здійснення платежу за акредитивом). Авторами виділяється дві основні функції розрахунків: проведення розрахунку та сплата кредитору певної грошової суми на визначений рахунок, також зазначено, що розрахунки можуть проводитися з метою зарахування зустрічних вимог, або можуть бути спрямовані на переказ коштів [15].

На основі досліджень проведених щодо економічних, облікових, банківських, юридичних сторін теоретичних засад розрахунків здійснено їх класифікацію та порівняння за критеріями сутності поняття, форм прояву та форм здійснення, які наведено у табл. 1

Наведені дані у таблиці представляють взаємозв'язок розмежування підходів до економічного трактування поняття «розрахунки» та форми прояву для цілей бухгалтерського обліку та оподаткування, права, банківської справи. Це вимагає безпосереднього або опосередкованого відображення в системі бухгалтерського обліку всіх складових розрахунків що стосуються об'єкту, суб'єктів, форм здійснення та додаткових наслідків здійснення розрахунків.

В загальній системі розрахунків одне з важливих місць займають розрахунки з покупцями, які мають певну специфіку таких елементів, як об'єкт, суб'єкт і механізм розрахунків. Об'єктом системи розрахунків з покупцями $\epsilon$ взаємовідносини та фінансові зобов'язання між покупцями та продавцями. Суб'єктами виступають покупці товарів, робіт, послуг платники коштів. 
ПОРІВНЯННЯ СУТНОСТІ ПОНЯТТЯ «РОЗРАХУНОК» 3 РІЗНИХ ТОЧОК ЗОРУ

\begin{tabular}{|c|c|c|c|c|c|}
\hline Критерій & $\begin{array}{c}\text { Економічна } \\
\text { сутність }\end{array}$ & $\begin{array}{l}\text { Облікова } \\
\text { сутність }\end{array}$ & $\begin{array}{l}\text { Податкова } \\
\text { сутність }\end{array}$ & $\begin{array}{c}\text { Банківська } \\
\text { сутність }\end{array}$ & $\begin{array}{l}\text { Юридична } \\
\text { сутність }\end{array}$ \\
\hline $\begin{array}{l}\text { Сутність } \\
\text { поняття }\end{array}$ & Платіж & $\begin{array}{l}\text { Визначення умов } \\
\text { платежу }\end{array}$ & $\begin{array}{l}\text { Облікові проце- } \\
\text { дури суворо ре- } \\
\text { гламентовані дер- } \\
\text { жавою }\end{array}$ & $\begin{array}{l}\text { Платіж } 3 \text { метою } \\
\text { повного або част- } \\
\text { кового погашен- } \\
\text { ня грошового зо- } \\
\text { бов'язання }\end{array}$ & $\begin{array}{l}\text { Рух грошових } \\
\text { коштів }\end{array}$ \\
\hline $\begin{array}{l}\text { Форми } \\
\text { прояву }\end{array}$ & $\begin{array}{l}\text { Взаємовідноси- } \\
\text { ни } 3 \text { приводу } \\
\text { погашення } 30- \\
\text { бов'язань }\end{array}$ & $\begin{array}{l}\text { В і д о б р а же н - } \\
\text { ня дебіторської } \\
\text { та кредиторської } \\
\text { заборгованості }\end{array}$ & $\begin{array}{l}\text { Надання інфор- } \\
\text { мації про нара- } \\
\text { хування та сплату } \\
\text { податків податко- } \\
\text { вим органам }\end{array}$ & $\begin{array}{l}\text { Проведення розра- } \\
\text { хунків за валютні } \\
\text { цінності та фінан- } \\
\text { сові інструменти }\end{array}$ & $\begin{array}{l}\text { В и н и к н ен н я } \\
\text { та погашення } \\
\text { зобов'язань }\end{array}$ \\
\hline $\begin{array}{l}\text { Форми } \\
\text { здійснення }\end{array}$ & $\begin{array}{l}\text { Розмежування } \\
\text { об'єкту та фор- } \\
\text { ми розрахунків }\end{array}$ & $\begin{array}{l}\text { Облік руху фінан- } \\
\text { сових потоків }\end{array}$ & $\begin{array}{l}\text { База оподатку- } \\
\text { вання }\end{array}$ & $\begin{array}{l}\text { Здійснення пла- } \\
\text { тежів тільки за } \\
\text { розпорядженням } \\
\text { власника рахунка }\end{array}$ & $\begin{array}{l}\text { Нор мативне } \\
\text { регулювання } \\
\text { форми розра- } \\
\text { хунків, цінних } \\
\text { паперів }\end{array}$ \\
\hline
\end{tabular}

Джерело: узагальнено автором за джерелами [1-15]

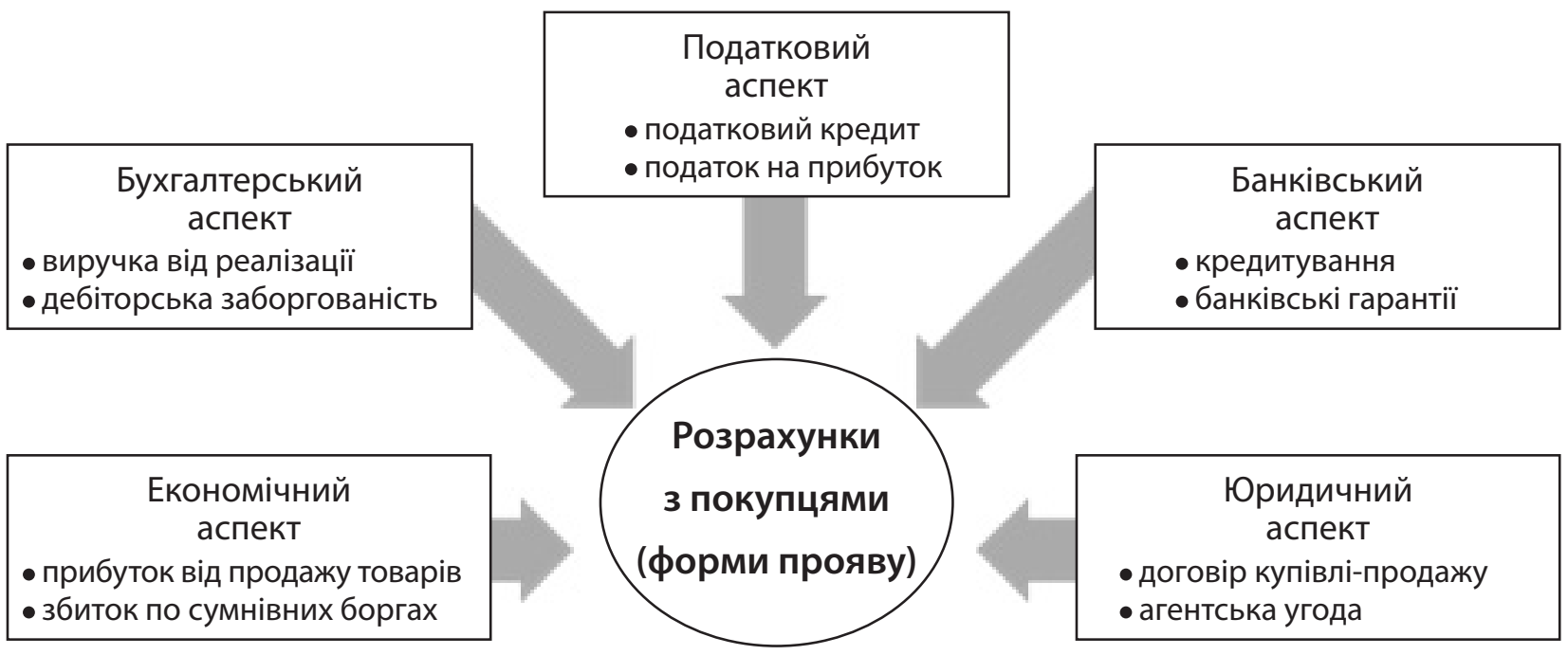

Puc. 1. Характеристика форм прояву розрахунків з покупцями за різними аспектами

Джерело: складено автором за джерелами [3-15]

Метою здійснення розрахунків для покупців є максимальне наближення моменту передачі товарів, робіт, послуг. Звідси основна мета системи розрахунків з покупцями - гарантоване виконання зобов'язань покупців перед постачальниками в оптимальний для двох сторін проміжок часу між моментом передачі товарів, робіт, послуг та отримання коштів.

Здійснюючи свою операційну діяльність торгові підприємства та організації вступають в розрахункові взаємовідносини з іншими підприємствами, організаціями та кінцевими споживачами. Ці розрахунки перш за все пов'язані 3 реалізацією товарів та обліком розрахунків з покупцями за придбані товари. Для визначення кола питань, що вже дослідженні та досліджені частково, нами проведено аналіз останніх наукових робіт з питань обліку розрахунків 3 покупцями. Отримані результати наведені у маблиці 2. 
АНАЛІЗ ДОСЛІДЖЕНЬ ЩОДО ПИТАНЬ ОБЛІКУ РОЗРАХУНКІВ 3 ПОКУПЦЯМИ

\begin{tabular}{|c|c|c|}
\hline Автори, джерела & Проблематика & Пропозиції \\
\hline $\begin{array}{l}\text { 1. Акімова Н.С., } \\
\text { Топоркова О.В., } \\
\text { Євлаш Т.О., } \\
\text { Говоруха О.О. } \\
{[16]}\end{array}$ & $\begin{array}{l}\text { Удосконалення обліку } \\
\text { та аналізу дебіторської } \\
\text { заборгованості в } \text { си- } \\
\text { стемі управління під- } \\
\text { приємств оптової тор- } \\
\text { гівлі }\end{array}$ & $\begin{array}{l}\text { Систематизовано класифікацію дебіторської заборгованості } \\
\text { у Балансі та Плані рахунків. за часовим розрізом, за об’єктами } \\
\text { виникнення зобов’язань (виділення розрахунків за бартер- } \\
\text { ними операціями) за податковими наслідками; можливістю } \\
\text { уступки прав вимог; своєчасністю погашення; ймовірністю } \\
\text { погашення; терміном погашення; наявністю наміру; формою } \\
\text { існування; в залежності від прийняття заходів щодо погашен- } \\
\text { ня на підприємствах оптової торгівлі. Систематизовано види } \\
\text { оцінки дебіторської заборгованості: первісна оцінка, колек- } \\
\text { торська оцінка та оцінка сек'юритизації, що виникає при по- } \\
\text { гашенні заборгованості }\end{array}$ \\
\hline $\begin{array}{l}\text { 2. Бенько М. М. } \\
{[17-20]}\end{array}$ & $\begin{array}{l}\text { Особливості організації } \\
\text { обліку на торгівельному } \\
\text { підприємстві в умовах } \\
\text { сучасних інформацій- } \\
\text { них технологій }\end{array}$ & $\begin{array}{l}\text { Визначено показники прямої економічної ефективності зни- } \\
\text { ження дебіторської заборгованості при впровадженні автома- } \\
\text { тизованої системи бух обліку. Доведено зниження дебіторсь- } \\
\text { кої заборгованості за рахунок всебічного, персоніфікованого } \\
\text { контролю на десятки процентів }\end{array}$ \\
\hline $\begin{array}{l}\text { 3. Богатенко Н. } \\
{[21]}\end{array}$ & $\begin{array}{l}\text { Відображення знижки } \\
\text { в обліку, відсутність } \\
\text { інформації про знижки } \\
\text { у фінансовій звітності; } \\
\text { документи при наданні } \\
\text { знижок }\end{array}$ & $\begin{array}{l}\text { Запропоновано класифікацію знижок, розглянуто валовий } \\
\text { і чистий методи відображення знижок; відображати суму на- } \\
\text { даних знижок на рахунку } 719 \text { у покупця; при наданні знижки } \\
\text { рекомендується виписувати нові накладні, рахунки-фактури } \\
\text { та анулювати попередні, подавати уточнюючі податкові де- } \\
\text { кларації. Сума знижки у покупця відображається на рахунках } \\
\text { інших доходів }\end{array}$ \\
\hline $\begin{array}{l}\text { 4. Бойко В.В., } \\
\text { Пістунов I.М., } \\
\text { Пашкевич М.С. } \\
{[22]}\end{array}$ & $\begin{array}{l}\text { Оптимізація дебіторсь- } \\
\text { кої заборгованості }\end{array}$ & $\begin{array}{l}\text { Запропоновано матрицю динаміки доходів і витрат у про- } \\
\text { сторі зміни суми боргу та відстрочки в залежності від їх } \\
\text { співвідношення до операційних витрат та норм запасів то- } \\
\text { вару. Для договорів купівлі-продажу з відстрочкою платежу } \\
\text { (опціони, ф’ючерси, деривативи) пропонується додатковий } \\
\text { пункт «Особливі умови» з матрицею. }\end{array}$ \\
\hline $\begin{array}{l}\text { 5. Булкат Г. } \\
\text { [23] }\end{array}$ & $\begin{array}{l}\text { Проблеми оцінки дебі- } \\
\text { торської } \\
\text { ності по фаборгова- } \\
\text { операціях таринових } \\
\text { ження знижок }\end{array}$ & $\begin{array}{l}\text { Запропоновано відображати в обліку знижки у продавця (при } \\
\text { наданні знижки до реалізації товарів знижка в обліку не відо- } \\
\text { бражається; при наданні знижки після реалізації товарів слід } \\
\text { додавати виписку з документів, що підтверджують факт надан- } \\
\text { ня знижки, а суму знижки відображати сторнуючими прове- } \\
\text { деннями; при наданні знижки, в рахунок зменшення дебітор- } \\
\text { ської заборгованості, відображається як безоплатна передача } \\
\text { товарів покупцю на суму знижки). Облік знижок у покупця } \\
\text { (при отриманні знижки до відображення вартості придбаних } \\
\text { товарів в бухгалтерському обліку не відображається; при отри- } \\
\text { манні знижки після відображення операцій з придбання змен- } \\
\text { шується заборгованість перед постачальником та собівартість } \\
\text { товарів або кредиторська заборгованість та збільшуються нео- } \\
\text { пераційні доходи). При наданні знижок є обов’язковим надан- } \\
\text { ня уточнюючих документів, що підтверджують факт отриман- } \\
\text { ня знижки з подальшим корегуванням податкового кредиту. }\end{array}$ \\
\hline $\begin{array}{l}\text { 6. Євлаш Т.О. } \\
{[24]}\end{array}$ & $\begin{array}{l}\text { Удосконалення обліку } \\
\text { та аналіз дебіторської } \\
\text { заборгованості в си- } \\
\text { стемі управління }\end{array}$ & $\begin{array}{l}\text { Запропоновано змінити найменування рахунка } 38 \text { «Резерв } \\
\text { сумнівних боргів» на «Резерв можливих втрат від боргів» } 3 \text { ви- } \\
\text { окремленням субрахунків: } 381 \text { «Резерв безнадійної заборгова- } \\
\text { ності» та } 382 \text { «Витрати на погашення дебіторської заборгова- } \\
\text { ності». Запропоновано відображати суму знижки після дати } \\
\text { реалізації на аналітичному рахунку }-704.1 \text { «нижки, надані } \\
\text { після дати реалізації»; автоматизованої системи обліку - за- } \\
\text { пропоновано здійснювати нарахування резерву сумнівних бор- } \\
\text { гів у підсистемі «Бухгалтерський облік» «1С: Управління торго- } \\
\text { вельним підприємством 8» в документі «Коригування боргу». }\end{array}$ \\
\hline
\end{tabular}


Продовження табл. 2

\begin{tabular}{|c|c|c|}
\hline Автори, джерела & Проблематика & Пропозиції \\
\hline $\begin{array}{l}\text { 7. Жуков Н.В. } \\
{[25]}\end{array}$ & $\begin{array}{l}\text { Відсутність класифіка- } \\
\text { ції знижок у бухгал- } \\
\text { терському } \\
\text { недосконалість заліку, } \\
\text { нодавчо-нормативно- } \\
\text { го регулювання обліку } \\
\text { знижоку покупця }\end{array}$ & $\begin{array}{l}\text { Запропоновано класифікацію знижок та порядок відобра- } \\
\text { ження їх в обліку. При отриманні знижки до відображен- } \\
\text { ня вартості придбаних товарів знижка в обліку не відобра- } \\
\text { жається; при отриманні знижки після відображення операцій } \\
\text { з придбання зменшується заборгованість перед постачальни- } \\
\text { ком та собівартість товарів або кредиторська заборгованість, } \\
\text { збільшуються неопераційні доходи. При наданні знижок є } \\
\text { обов’язковим надання документів, що підтверджують факт } \\
\text { отримання знижки з подальшим корегуванням податково- } \\
\text { го кредиту та зобов'язання у покупця та продавця. Дохід, } \\
\text { отриманий від надання знижки, розглядається як різновид } \\
\text { валового доходу від реалізації товарів. Наводиться формула } \\
\text { розрахунку середньої торгової знижки за середньозваженим } \\
\text { методом оцінки товарів в торгових організаціях. Пропонуєть- } \\
\text { ся виділити окремий субрахунок «Торгова знижка». }\end{array}$ \\
\hline $\begin{array}{l}\text { 8. Закревська О.Ю. } \\
{[26]}\end{array}$ & $\begin{array}{l}\text { Дебіторської заборго- } \\
\text { ваності в торгівлі }\end{array}$ & $\begin{array}{l}\text { Запропоновано класифікацію поточної дебіторської заборго- } \\
\text { ваності, оподаткування доходів при реалізації товарів з зниж- } \\
\text { кою, порівняльний аналіз П(С)БО та МСФО, запропоновано } \\
\text { відомість обліку поточної дебіторської заборгованості }\end{array}$ \\
\hline $\begin{array}{l}\text { 9. Кияшко О.М. } \\
\text { [27] }\end{array}$ & $\begin{array}{l}\text { Удосконалення доку- } \\
\text { ментообігу управлін- } \\
\text { ського напрямку в си- } \\
\text { стемі організації обліку } \\
\text { дебіторської заборгова- } \\
\text { ності }\end{array}$ & $\begin{array}{l}\text { Запропоновано Впровадження системи бюджетування } \\
\text { дебіторської заборгованості. Рекомендовано створення вну- } \\
\text { трішнього стандарту управлінського обліку дебіторської за- } \\
\text { боргованості, бюджетного регламенту, бюджету дебіторської } \\
\text { заборгованості на рік і місяць, платіжного календаря. Крім } \\
\text { того організація обліку в управлінні дебіторською заборг-- } \\
\text { ваністю вимагає розробки «Наказу про систему управлінсь- } \\
\text { кого обліку підприємства» де необхідно вказати розроблені } \\
\text { нормативні акти, первинні документи та регістри управлінсь- } \\
\text { кого обліку дебіторської заборгованості підприємства }\end{array}$ \\
\hline $\begin{array}{l}\text { 10. Кузьмін Д.Л. } \\
{[28]}\end{array}$ & $\begin{array}{l}\text { Проблеми оподатку- } \\
\text { вання та відображен- } \\
\text { ня в бухгалтерському } \\
\text { обліку ПДВ та податку } \\
\text { на прибуток при розра- } \\
\text { хунках з покупцями }\end{array}$ & $\begin{array}{l}\text { Запропоновано у податковому обліку платнику податку ві- } \\
\text { докремити суми неустойки від сум відшкодування збитків. } \\
\text { Звернено увагу, що суми коштів, які не пов’язані з поставкою } \\
\text { товарів або послуг і які не є компенсацією вартості товарів } \\
\text { (послуг), не можуть розглядатися як об'єкт оподаткування } \\
\text { ПдВ. }\end{array}$ \\
\hline $\begin{array}{l}\text { 11. Педенко М.М., } \\
\text { Голубєва Т.В., } \\
\text { Крамський Д.Ю. } \\
\text { [29] }\end{array}$ & $\begin{array}{l}\text { Визначення інструмен- } \\
\text { тарію аналізу та оцінки } \\
\text { дебіторської заборгова- } \\
\text { ності }\end{array}$ & $\begin{array}{l}\text { Запропоновано перелік показників для оцінки дебіторської } \\
\text { заборгованості: коефіцієнт інкасації, коефіцієнт оборотності } \\
\text { дебіторської заборгованості, період погашення дебіторської } \\
\text { заборгованості, коефіцієнт погашення дебіторської заборго- } \\
\text { ваності, частка сумнівної заборгованості, частка дебіторської } \\
\text { заборгованості, коефіцієнт співвідношення між дебіторською } \\
\text { та кредиторською заборгованістю за розрахунковий період, } \\
\text { коефіцієнт ефективності вкладення коштів в дебіторську за- } \\
\text { боргованість. Для оцінки дебіторської заборгованості пропо- } \\
\text { нується вести реєстр старіння дебіторської заборгованості. }\end{array}$ \\
\hline $\begin{array}{l}\text { 12. Погоріляк Л.В. } \\
\text { [30] }\end{array}$ & $\begin{array}{l}\text { Удосконалення бухгал- } \\
\text { терського обліку взає- } \\
\text { морозрахунків }\end{array}$ & $\begin{array}{l}\text { Запропоновано списувати з балансу сумнівну заборгованість } \\
\text { лише тоді, коли вона перетворилась на безнадійну; резерв } \\
\text { сумнівних боргів визначати на підставі платоспроможності } \\
\text { окремих дебіторів, що дозволятиме відновлювати заборг- } \\
\text { ваність з коригуванням цього резерву; передбачити мож- } \\
\text { ливість проводити відрахування до резерву на підставі серед- } \\
\text { ніх статистичних даних, що дозволить спростити процедуру } \\
\text { відрахувань до резерву сумнівних боргів. Для удосконалення } \\
\text { обліку безнадійної заборгованості пропонується змінити на- } \\
\text { зву рахунку } 38 \text { «езерви сумнівних боргів» на «Коригування } \\
\text { на сумнівні борги». Для управління дебіторською заборг-- } \\
\text { ваністю, рекомендовано використовувати факторинг. }\end{array}$ \\
\hline
\end{tabular}




\begin{tabular}{|c|c|c|}
\hline Автори, джерела & Проблематика & Пропозиції \\
\hline $\begin{array}{l}\text { 13. Полятикін С.О. } \\
\text { [31] }\end{array}$ & $\begin{array}{l}\text { Розглядається пробле- } \\
\text { ма автоматизації обліку } \\
\text { розрахунків } 3 \text { покуп- } \\
\text { цями, взаємодії різних } \\
\text { інформаційних систем } \\
\text { між собою, між різни- } \\
\text { ми рівнями і групами }\end{array}$ & $\begin{array}{l}\text { Запропоновано створення інтегрованих інформаційних } \\
\text { систем, де автоматизація обліку розрахунків з покупцями } \\
\text { та замовниками є однією з складових загальної системи. Ін- } \\
\text { формаційне забезпечення автоматизованого робочого місця } \\
\text { з обліку розрахунків постачальників і замовників складаєть- } \\
\text { ся з: методичних та інструктивних матеріалів; системи кла- } \\
\text { сифікації та кодування інформації; інформаційної бази. }\end{array}$ \\
\hline $\begin{array}{l}\text { 14. Сахаров П.О. } \\
\text { [32] }\end{array}$ & 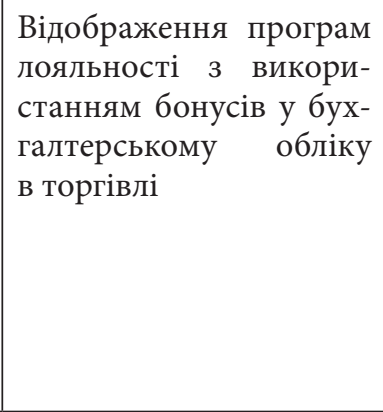 & $\begin{array}{l}\text { Доведено, що для забезпечення виплат бонусів клієнтам не- } \\
\text { обхідно резервувати частину коштів і відображати резерв бо- } \\
\text { нусів в обліку. Для накопичення інформації про рух коштів, } \\
\text { які резервуються підприємством для забезпечення майбутніх } \\
\text { витрат на виплату бонусів і посилення деталізації обліку про- } \\
\text { грам лояльності, рекомендується в робочому плані рахунків } \\
\text { торговельних підприємств відкривати окремий субрахунок } \\
479 \text { «езерв покритя бонусів», що дозволить більш повно за- } \\
\text { довольнити потреби управлінського персоналу в інформації } \\
\text { про ефективність програм лояльності }\end{array}$ \\
\hline $\begin{array}{l}\text { 15. Сухар I.C. } \\
\text { [33] }\end{array}$ & $\begin{array}{l}\text { Відображення на ра- } \\
\text { хунках бухгалтерського } \\
\text { обліку інформації про } \\
\text { розрахунки з покупця- } \\
\text { ми та замовниками }\end{array}$ & $\begin{array}{l}\text { Запропоновано для обліку розрахунків з покупцями та за- } \\
\text { мовниками використовувати синтетичний рахунок } 36 \text { «Роз- } \\
\text { рахунки з покупцями та замовниками» } 3 \text { трьома субрахунка- } \\
\text { ми. На підставі даних первинних бухгалтерських документів } \\
\text { інформацію про здійснені операції групують в облікових ре- } \\
\text { гістрах. Аналітичний облік ведеться за кожним пред’явленим } \\
\text { до сплати рахунком, за кожною операцією й забезпечує облік } \\
\text { заборгованості за розрахунками з покупцями }\end{array}$ \\
\hline $\begin{array}{l}\text { 16. Тараненко I.B., } \\
\text { Дрозденко А.В. } \\
\text { [34] }\end{array}$ & $\begin{array}{l}\text { Оцінка лояльності спо- } \\
\text { живачів роздрібної тор- } \\
\text { гівлі в умовах кризи }\end{array}$ & $\begin{array}{l}\text { Запропоновано використання шкали Лайкерта для розра- } \\
\text { хунку індексу лояльності. Зроблено висновок про скорочен- } \\
\text { ня рівня лояльності в період економічної кризи. }\end{array}$ \\
\hline $\begin{array}{l}\text { 17. Топоркова О. В. } \\
\text { [35] }\end{array}$ & $\begin{array}{l}\text { Визнання та оцінка } \\
\text { дебіторської заборгова- } \\
\text { ності }\end{array}$ & $\begin{array}{l}\text { Розкрито процедуру виникнення та визнання дебіторської } \\
\text { заборгованості в обліку. Подано перелік документів, що під- } \\
\text { тверджують визнання дебіторської заборгованості в бухгал- } \\
\text { терському обліку }\end{array}$ \\
\hline $\begin{array}{l}\text { 18. Фарйон О.О., } \\
\text { Яструбський М.Я. } \\
\text { [36] }\end{array}$ & $\begin{array}{l}\text { Удосконалення кон- } \\
\text { тролю та управління } \\
\text { дебіторською заборго- } \\
\text { ваністю, проблеми опо- } \\
\text { даткування }\end{array}$ & $\begin{array}{l}\text { Запропоновано перелік показників для оцінки дебіторської } \\
\text { заборгованості: коефіцієнт оборотності дебіторської забор- } \\
\text { гованості; тривалість періоду погашення дебіторської за- } \\
\text { боргованості, коефіцієнти платоспроможності, ліквідності. } \\
\text { Проблема визнання дебіторської заборгованості, яка пов’я- } \\
\text { зана із застосуванням гнучкої системи численних знижок. } \\
\text { Зазначено, що податкова адміністрація фактично зацікавле- } \\
\text { на лише у погашенні боргів підприємств перед бюджетом, } \\
\text { навіть за рахунок зростання заборгованості перед іншими } \\
\text { підприємствами, що є причиною уникнення оподаткування } \\
\text { та виведення коштів у «тінь». }\end{array}$ \\
\hline $\begin{array}{l}\text { 19. Фоміна О.В. } \\
\text { [37] }\end{array}$ & $\begin{array}{l}\text { Удосконалення класи- } \\
\text { фікації та оцінки де } \\
\text { біторської заборгова- } \\
\text { ності в оптовій торгівлі }\end{array}$ & $\begin{array}{l}\text { Запропоновано класифікацію дебіторської заборгованості } \\
\text { в торгівлі за рівнем кредитоспроможності покупців та на ос- } \\
\text { нові їх кредитної історії. Пропонується оцінювання дебітор- } \\
\text { ської заборгованості в управлінському балансі як актив, } \\
\text { умовний актив, збиток. }\end{array}$ \\
\hline
\end{tabular}

Джерело: узагальнено автором за джерелами [16-37]

Аналіз попередніх публікацій та досліджень показав, що питання обліку розрахунків 3 покупцями та замовниками досліджуються в різних напрямках: починаючи від загальних досліджень розрахунків з покупцям та замов- никами [21], [22], [25], [28], [33] до грунтовного дослідження питань обліку та управління дебіторською заборгованістю підприємств [16], [17-20], [23], [24], [26], [27], [29], [30], [31], [35], [36], [37], а також систем лояльності [32], [34]. 
Іншим напрямком досліджень виступають дослідження у випадку врахування особливостей розрахунків з покупцями та замовниками в залежності від галузі економіки: оптова [16], [26], [37] та роздрібна торгівля [17-20], [25], [32],

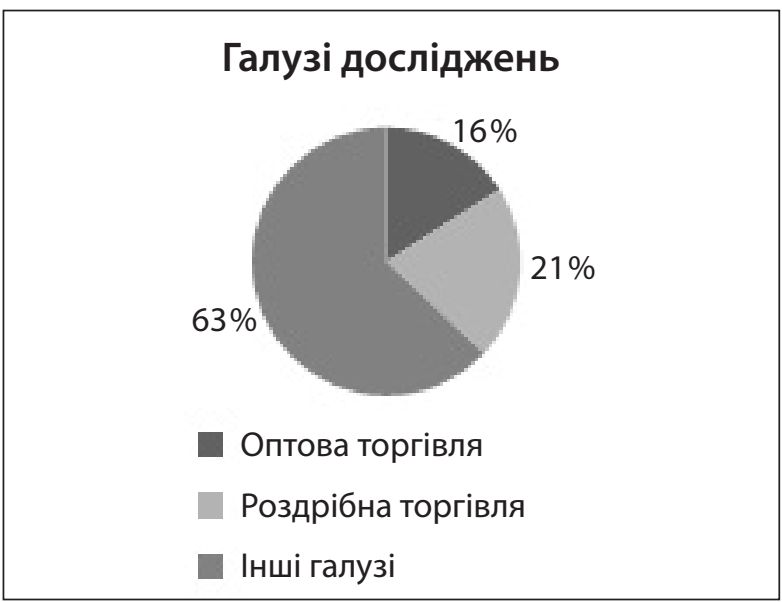

[34], інші невизначені галузі [21], [22], [23], [24], [27], [28], [29], [30], [31], [33], [35], [36]. Ha ocнові вище наведеної класифікації напрямків досліджень щодо обліку розрахунків з покупцями побудуємо рисунок 2.

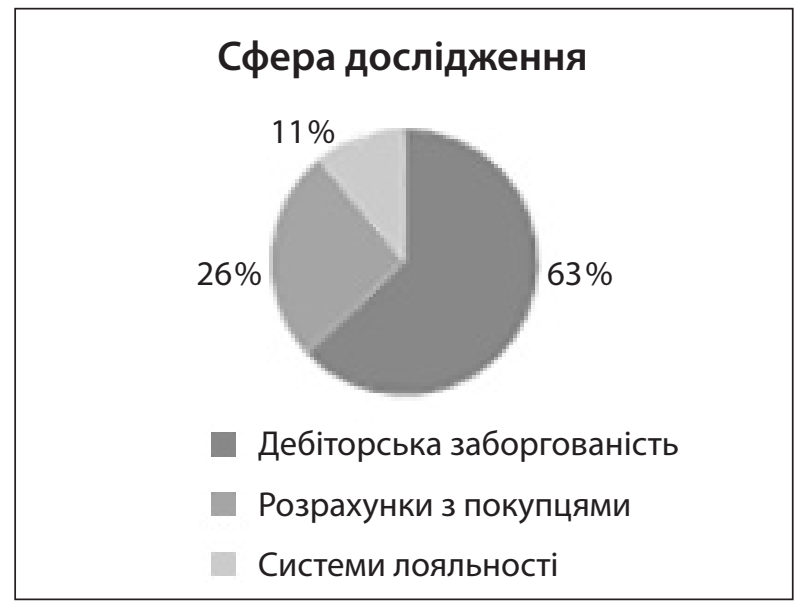

Puc. 2. Структура напрямків досліджень обліку розрахунків з покупцями за галузями та сферами

Джерело: складено автором за джерелами [16-37]

Систематизація поглядів наведена на рисунку 2 свідчить, що найбільшу увагу науковці (63 \%) зосереджують на дослідженнях загальних напрямків вдосконалення бухгалтерського обліку розрахунків з покупцями. Разом з тим, лише $16 \%$ та $21 \%$ науковців обрали об'єктом дослідження, вивчення особливостей обліку розрахунків з покупцями відповідно в оптовій та роздрібній торгівлі.

Моніторинг напрямків досліджень обліку розрахунків з покупцями за різними сферами, наукові погляди на дане питання умовно розділились на три групи.

До першої групи (63 \%) відносяться автори, які вважають, що облік розрахунків з покупцями - це переважно дослідження дебіторської заборгованості, що виникає при розрахунках на умовах після оплати та від термінування платежів.

До другої групи (26 \%) відносяться науковці, які вважають, що облік розрахунків з покупцями - це переважно облік виставляння рахунків на сплату та відображення оплат покупців за різними формами розрахунків, в т.ч. оплата дебіторської заборгованості.

Третя група вчених (11\%) вважає перспективним напрямком досліджень обліку розрахунків з покупцями - вивчення питань щодо створення та управління системами лояльності для покупців та розрахунках з ними, тобто облік розрахунків з покупцями, який орієнтований на активні продажі та оперативне управління розрахунками з покупцями з використанням IT та Інтернет технологій.

Аналіз останніх досліджень 3 питань обліку розрахунків з покупцями показав, що за результатами проведених досліджень науковцями було запропоновано ряд пропозицій щодо вирішення визначених проблем, зокрема, вдосконалення класифікації та оцінки відображення в обліку розрахунків з покупцями, впровадження додаткових аналітичних та синтетичних рахунків, вдосконалення первинних документів та звітності загалом. На основі отриманих результатів побудовано таблищю 3.

Дані таблиці 3 показують, що вирішення питань обліку розрахунків з покупцями автори вбачають в уточненні класифікації основних понять, у вдосконаленні методики оцінки відображення в обліку розрахунків з покупцями і замовниками, введенні додаткових синтетичних та аналітичних рахунків, вдосконаленні первинних документів та деталізації фінансової звітності з обліку розрахунків з покупцями i замовниками. Рядом авторів запропоновано систематизацію показників для аналізу розрахунків з покупцями у т.ч. дебіторської заборгованості, а також уточнення проблем оподаткування розрахунків з покупцями в умовах надання знижок та впровадження інформаційних технологій в процес обліку та управління 
розрахунків з покупцями. Наочне відображення даних таблиці 3 щодо глибини досліджень за кожним видом опрацьованих авторами питань показано на рисунок 3.

Відповідно до даних рисунку 3, пропозиції щодо вдосконалення обліку розрахунків з покупцями повинні стосуватися вдосконалення класифікації (5), методів оцінки в обліку (5), оподаткування (2) та автоматизації процесів обліку (3).

Зупиняючись на даному етапі досліджень проблемних питань бухгалтерського обліку розрахунків з покупцями в торгівлі слід виділити наступні питання, що потребують подальших досліджень:

- Відображення в реєстрах бухгалтерського обліку інформації про стан розрахунків з покупцями в торгівлі, їх подальше удосконалення зумовлене направленістю національних П(С) БО до міжнародних стандартів фінансової звітності (МСФЗ).

- Класифікація розрахунків 3 покупцями в роздрібній та оптовій торгівлі, систематизація факторів та показників систем лояльності в торгівлі, що суттєво впливають на управління та облік розрахунків за товари із знижками.

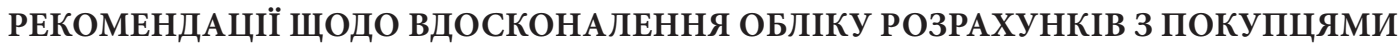

\begin{tabular}{|c|c|c|c|c|c|c|c|}
\hline Автори, джерела & 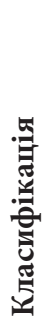 & 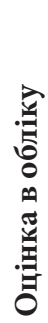 & 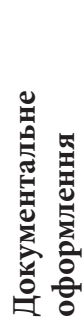 & 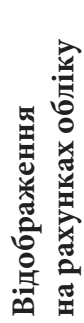 & 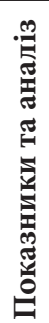 & 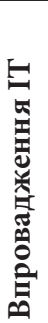 & 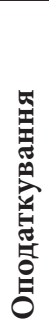 \\
\hline 1. Акімова Н.С., Топоркова О.В., Євлаш Т.О., Говоруха О.О.[16] & $\mathrm{x}$ & $\mathrm{x}$ & & & & & \\
\hline 2. Бенько М.М. [2] & & & $\mathrm{x}$ & & & $\mathrm{x}$ & \\
\hline 3. Богатенко Н. [21] & $\mathrm{x}$ & & & $\mathrm{x}$ & & & \\
\hline 4. Бойко В.В., Пістунов I.М., Пашкевич М.С [22 & & & $\mathrm{x}$ & & $\mathrm{x}$ & & \\
\hline 5. Булкат Г. [23] & & $\mathrm{x}$ & $\mathrm{x}$ & $\mathrm{x}$ & & & \\
\hline 6. Євлаш Т.О. [24] & & & & $\mathrm{x}$ & & $\mathrm{x}$ & \\
\hline 7. Жуков Н.В. [25] & $\mathrm{x}$ & & $\mathrm{x}$ & $\mathrm{x}$ & $\mathrm{x}$ & & \\
\hline 8. Закревська О.Ю.[26] & $\mathrm{x}$ & & $\mathrm{x}$ & & & & \\
\hline 9. Кияшко О.М.[27] & & & $\mathrm{x}$ & & $\mathrm{x}$ & & \\
\hline 10. Кузьмін Д.Л [28] & & & & $\mathrm{x}$ & & & $\mathrm{x}$ \\
\hline 11. Педенко М.М., Голубєва Т.В., Крамський Д.Ю [2] & & & $\mathrm{x}$ & & $\mathrm{x}$ & & \\
\hline 12. Погоріляк Л.В. [30] & & & & $\mathrm{x}$ & $\mathrm{x}$ & & \\
\hline 13. Полятикін С.О. [31] & & & & & & $\mathrm{x}$ & \\
\hline 14. Сахаров П.О. [32] & & & & $\mathrm{x}$ & & & \\
\hline 15. Cyxap I.C. [33] & & $\mathrm{x}$ & & $\mathrm{x}$ & & & \\
\hline 16. Тараненко І.В., Дрозденко А.В.[34] & & & & & $\mathrm{x}$ & & \\
\hline 17. Топоркова О. В.[35] & & $\mathrm{x}$ & $\mathrm{x}$ & & & & \\
\hline 18. Фарйон О.О., Яструбський М.Я.[36] & & & & & $\mathrm{x}$ & & $\mathrm{x}$ \\
\hline 19. Фоміна О.В.[37] & $\mathrm{x}$ & $\mathrm{x}$ & & & & & \\
\hline
\end{tabular}

Джерело: узагальнено автором за джерелами [16-37] 
- Опрацювання єдиного підходу до розрахунку, оцінки та відображення в обліку знижок, бонусів, винагород та інших заохочень, як у покупця, так і в продавця при застосуванні систем лояльності в торгівлі.

- Визначення впливу застосування систем лояльності при розрахунках з покупцями з урахуванням знижок на базу оподаткування доходів та розмір податкових зобов'язань на додану вартість товарів
- Застосування систем лояльності торгових підприємств в умовах динамічного розвитку процесів автоматизації обліку знижок при розрахунках з покупцями.

Таким чином, питання розрахунків з покупцями та ефективного управління дебіторською заборгованістю є ключовими питаннями для торгівельних підприємств та організацій в умовах нових економічних відносин.

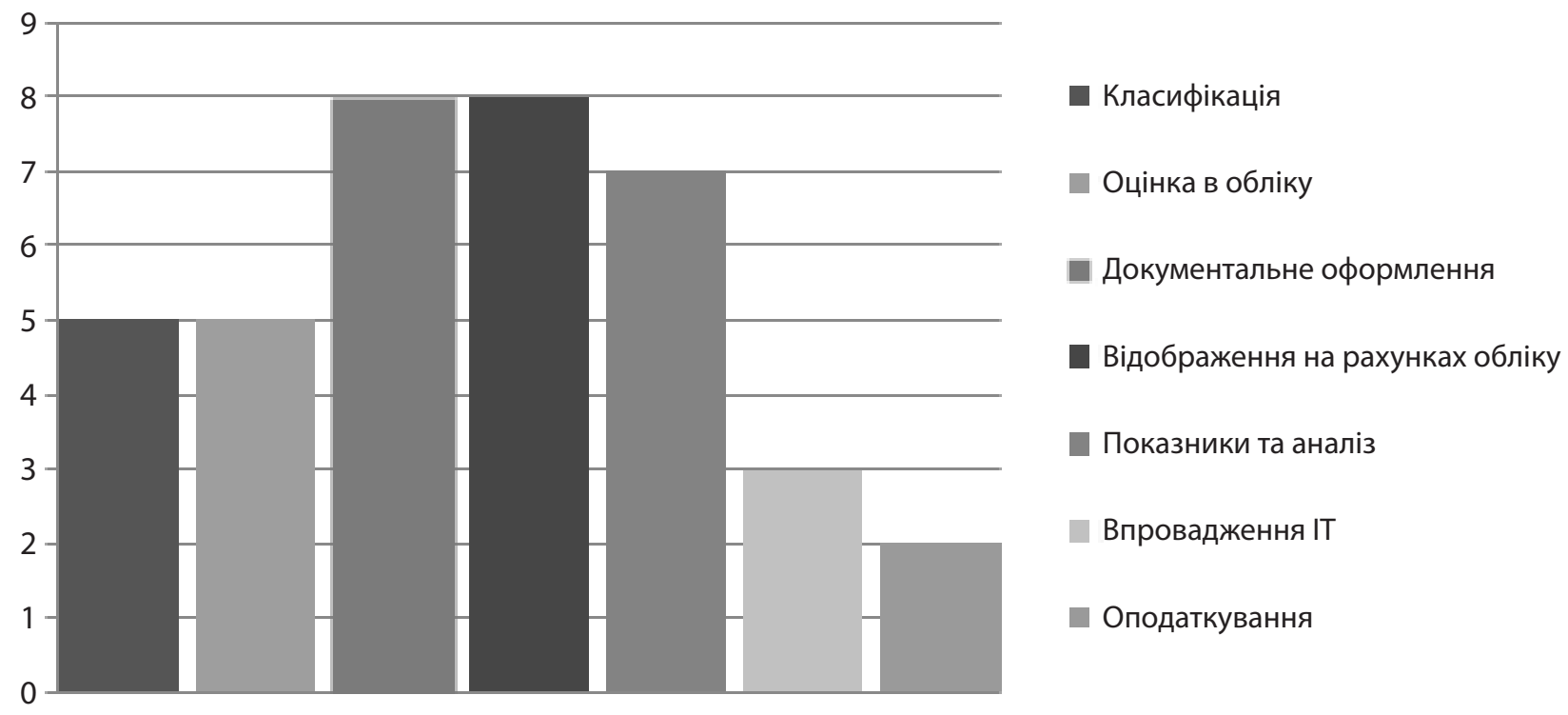

Puc. 3. Рекомендації щодо вдосконалення обліку розрахунків з покупцями в торгівлі

Джерело: складено автором за джерелами [16-37]

Оскільки бухгалтерський облік не може бути відокремленим від суспільно-економічних змін, він покликаний максимально сприяти впровадженню різних видів програм лояльності і особливо в торгівлі. Отже, подальшим напрямом наукового дослідження $€$ розробка методики бухгалтерського обліку розрахунків з покупцями в торгівлі в умовах застосування програм лояльності та практичного застосування оцінки доходності від реалізації цих програм [38-39]. Також, перспективними напрямками дослідження $є$ питання систематизації та класифікації елементів обліку та ефективного управління розрахунків з покупцями, визначення їх відмінностей в сфері оптової та роздрібної торгівлі, удосконалення методики обліку та обчислення знижок, бонусів, винагород покупцям при придбанні товарів, автоматизація та синергія систем лояльності та бухгалтерських програм.

\section{ПОДЯКА}

Висловлюю щиру подяку завідувачу кафедри обліку та оподаткування Київського національного торговельно-економічного університету, доктору економічних наук, Фоміній Олені Володимирівні та професору кафедри обліку та оподаткування Київського національного торговельно-економічного університету, відміннику освіти, доктору економічних наук, Бенько Миколі Миколайовичу за значний внесок в формування економічного мислення та сприяння щодо визначення наукової новизни тематики досліджень.

Окрему подяку висловлюю завідувачу кафедри фінансів та економіки Київського університету імені Бориса Грінченка, доктору економічних наук, Рамському Андрію Юрійовичу за надання фінансової підтримки в публікації статті. 


\section{СПИСОК ВИКОРИСТАНИХ ДЖЕРЕЛ}

1. Азрилиян, А.Н. (Ред.). (1999). Больщой бухгалтерский словарь. М.: Институт новой экономики.

2. Пантелєєв, В.П., Сніжко, О.С. (2009). Словник бухгалтера та аудитора. К.: ДП «Інформац.-аналіт. агентство».

3. Безруких, П.С. (Ред.). (1999). Бухгалтерский учет. М.: Бух. учет.

4. Парашутин, Н.В., Козлова, Е.П. (1999). Курс бухгалтерского учета. М.: Финансы.

5. Пархоменко, В.М. (2010). Розрахунки з покупцями та замовниками: обліковий аспект. Економічні науки, 3 (61), 142-145.

6. Райан, Б. (1998). Стратегический учет для руководителя. М.: Аудит, ЮНИТИ.

7. Березина, М.П. (1997). Безналичные расчеты в экономике России: Анализ практики. М.: АО «Консалтбанкир».

8. Власова І.О. (2005). Облік розрахунків з дебіторами та кредиторами. (Дис. канд. екон. наук). Національний аграрний університет, Київ.

9. Податковий кодекс України. №2755 - VI. (2010).

10. Бутинець, Ф.Ф. (2005). Бухгалтерський і фінансовий облік. Житомир: ПП «Рута».

11. Сердюк, В.М. (2005). Податковий облік. К.: Центр навчальної літератури.

12. Малишкін, О. (2009). Про статус податкового обліку українського підприємства. Бухгалтерський облік і аудит, 2, 48-57.

13. Д’яконова, I.I. (2012). Методологічні основи формування системи фінансового менеджменmу банку. Суми: Університетська книга.

14. Подцерковний О.П. (1999). Організаційно-правові основи розрахункових відносин у господарському комплексі України (Автореф. дис. канд. юрид. наук) НАН України. Інститут економічно-правових досліджень, Донецьк.

15. Дзера, О.В., Кузнєцова, Н.С. (2003). Цивільне право України. О.В.Дзера (Ред.), Гроші як об'єкт цивільних правовідносин (книга 1). (с. 153-160). Київ: Юрінком Інтер.

16. Акімова, Н.С., Топоркова, О.В., Євлаш, Т.О. \& Говоруха О.О. (2016). Облік та аналіз дебіторської заборгованості в системі управління підприємств оптової торгівлі. Харків: ХДУХТ.

17. Бенько, М.М. (2001). Автоматизація обліку товарів і товарообігу на підприємствах оптової торгівлі. Наукові записки, 9, 94-98.

18. Бенько, М.М. (Ред.). (2011). Особливості організаиії бухгалтерського обліку на торгівельному підприємстві в умовах сучасних інформаційних технологій. Матеріали V Міжнародної науково.-практичної конференції Конкурентоспроможність в умовах глобалізації: реалії, проблеми та перспективи. Житомир: Житомир. філія Київ. ін-ту бізнесу та технологій.

19. Бенько, М.М. (2002). Організація автоматизованого обліку товарів на підприємствах роздрібної торгівлі. Економіка: проблеми теорії та практики, 154, 7-11.

20. Бенько, М.М. (2000). Автоматизація бухгалтерського обліку роздрібної торгівлі в системі менеджменту підприємства. Економіка: проблеми теорії та практики, 46, 21-25.

21. Богатенко, Н. (2007). Знижки: облік у продавця і покупця. Бухгалтерія, 14, 50-52.

22. Бойко, B.I, Пістунов, І.М., Пашкевич, М.С. (2006). Оптимізація дебіторської заборгованості підприємства в ринкових умовах України. Науковий вісник НГУ, 7, 99-104.

23. Булкат, Г. (2010). Оцінка дебіторської заборгованості по факторингових операціях. Економіка, 1 (101), 11-16.

24. Євлаш, Т.О. (2012). Облік та аналіз дебіторської заборгованості в системі управління підприємств оптової торгівлі (Автореф. дис. канд. екон. наук) Харківський державний університет харчування та торгівлі, Харків.

25. Жуков, В.Н. (2008). Постачальник надав покупцю знижку: що повинен знати бухгалтер? Бухгалтерский учет, 3, 52-59.

26. Закревська, О.Ю. (2017). Організація бухгалтерського обліку поточної дебіторської заборгованості підприємства торгівлі. Причорноморські економічні студіï, 20, 103-106.

27. Кияшко О.М. (2011). Облік та аналіз дебіторської заборгованості в системі управління підприємством. ( Дис. канд. екон. наук). Київський національний торгово-економічний університет, Київ.

28. Кузьмін, Д.Л. (2011). Бухгалтерський облік і контроль процесу придбання майна: теорія i методика. (Автореф. дис. канд. екон. наук). Житомирський Державний Технологічний. університет, Житомир. 
29. Педенко, Н.Н. (2012). Управление дебиторской задолженностью. Вісник національного технічного університету «ХПI», 4, 127-136.

30. Погоріляк, Л.В. (Ред.). (2007). Організація обліку і аналізу розрахунків з покупиями і замовниками за національними та міжнародними стандартами. Матеріали підсумкової науково-практичної конференції студентів та аспірантів ЗакДУ. Ужгород: ЗакДУ.

31. Полятикін, С.О. (2005). Використання інформаційних систем в обліку розрахунків з покупцями та замовниками. Облік та аудит: теорія, практика, перспективи, 5, 188-189.

32. Сахаров, П.О. (2013). Відображення програм лояльності з використанням бонусів у бухгалтерському обліку. Бізнес Інформ, 10, 316-321.

33. Сухар, I.С. (Ред.) (2009). Аналітичний та синтетичний облік розрахунків з покупиями та замовниками. Матеріали VII міжнародної наукової конференції присвяченої пам'яті О.С. Бородкіна «Розвиток системи обліку, аналізу та аудиту в Україні: теорія, методологія, організація». Київ: НАСОА.

34. Тараненко, І.В. (2015) Дослідження і оцінка лояльності споживачів роздрібної торговельної мережі в умовах економічної кризи. Взято з: http://www.economy.nayka.com.ua/?op=1\&z=4038

35. Топоркова, О.В. (2011). Розрахунки з різними дебіторами в обліковому аспекті. Економічна стратегія і перспективи розвитку сфери торгівлі та послуг, 2 (14), 136-143.

36. Фарйон, О.О. (2011). Дебіторська та кредиторська заборгованість: контроль та управління як запорука успішного розвитку. Науковий вісник НЛТУ Украӥни, 21 (4), 276-282.

37. Фоміна, О.В. (2014). Вплив тенденцій в оптовій торгівлі на розвиток управлінського обліку. Вісник ОНУ ім. Мечнікова, 19 (2/6), 121-125.

38. Соболєва-Терещенко, О.А., Жарнікова, В.В. (2017). Теоретико-методологічні основи формування ефективних систем лояльності. Журнал Менеджер, 2(75), 82-91.

39. Соболєва-Терещенко, О.А., Жарнікова, В.В. (2017). Особливості бухгалтерського обліку розрахунків з покупцями в умовах застосування програм лояльності. Науковий вісник Ужгородського університету. Серія «Економіка», 2 (50), 325-332.

\title{
УЧЕТ РАСЧЕТОВ С ПОКУПАТЕЛЯМИ: СИСТЕМАТИЗАЦИЯ ВЗГЛЯДОВ И ПЕРСПЕКТИВЫ ИССЛЕДОВАНИЙ
}

\author{
Жарникова Валерия Владиславовна, \\ аспирант кафедры учета и налогообложения, \\ Киевский национальный торгово-экономический университет, \\ Киев, Украина \\ ORCID iD 0000-0002-4335-5149 \\ e-mail:v.zharnikova@gmail.com
}

\begin{abstract}
Аннотация. В статье исследовано научную и периодическую литературу по вопросу учета расчетов с покупателями за последние двадиать лет. Проанализировано сущность понятия «расчеты», дано характеристику сущности, форм проявления и форм проведения расчетов по различным аспектам, в том числе: экономическому, бухгалтерскому, налоговому, банковскому и юридическому.

В системе расчетов детализировано формы проявления расчетов с покупателями по вышеперечисленным аспектам. Определено, что формой проявления экономического аспекта расчетов с покупателями является прибыль от продажи товаров и ущерб по сомнительным долгам, бухгалтерского аспекта - выручка от реализации и дебиторская задолженность, налогового аспекта - налоговый кредит и налог на прибыль, банковского аспекта кредитование и банковские гарантии, юридического аспекта- договора купли-продажи и агентские соглашения.

Рассмотрено различные подходы к проблематике последних публикаций по тематике расчетов с покупателями и определен круг вопросов, которые достаточно широко исследованы и частично. Проведен глубокий анализ исследований и осуществлена систематизация взглядов ученых и практиков по вопросам учета расчетов с покупателями. Рассмотренные научные и практические публикации распределено по отраслевой направленности исследования на три группы: оптовая торговля, розничная торговля, другие отрасли. По сферам исследования публикации систематизировано тоже на три группы: дебиторская задолженность, расчеты с покупателями, системы лояльности.
\end{abstract}


Рекомендации по совершенствованиюучета расчетов с покупателями, изложенные в исследуемых источниках классифицированы по семи направлениям, в том числе: классификация, оценка в бухгалтерском учете, документальное оформление и отражение в финансовой отчетности, отображение на счетах бухгалтерского учета, показатели оборотности и их анализ, внедрение информационных и Интернет-технологий, а также налогообложение. На базе проведенных исследований проблемных вопросов бухгалтерского учета расчетов с покупателями в торговле определено пять направлений, требующих дальнейших научных исследований.

Ключевые слова: расчеты; систематизачия; расчеты с покупателями; торговля; программы лояльности.

\title{
ACCOUNTING OF SETTLEMENTS WITH CUSTOMERS: SYSTEMATIZATION OF VIEWS AND PROSPECTS OF RESEARCHES
}

\author{
Valeriia Zharnikova, \\ Postgraduate Student \\ Assistant Lecturer of the Department of Accounting and Taxation, \\ Kyiv National University of Trade and Economics, \\ Kyiv, Ukraine \\ ORCID iD 0000-0002-4335-5149 \\ e-mail:v.zharnikova@gmail.com
}

\begin{abstract}
The article examines the scientific and periodical literature on the issue of accounting for settlements with customers over the past twenty years. Analyzes the essence of the concept of "payments", given the characteristics of them essence, describes forms of manifestation and the forms of calculations with clients on various aspects: economic, accounting, tax, banking and legal. In the payment system, the forms of payment settlement with customers are detailed according to the different aspects. Determined that the manifestation form of the economic aspect of payments with buyers is the profit from the sale of goods and the expense from doubtful accounts, of the accounting aspects - sales revenue and receivables, of the tax aspects - tax credits and income tax, of the banking aspects - credits and bank guarantees, of the legal aspects — sales contract and agency agreements.

Various approaches to the problems of recent publications on the subject of settlements with customers and identify the issues that are widely studied and partially. Conducted in-depth researching of practice and scientific analysis of publications, as result are systematizing the views of scientists and practitioners on the accounting of calculations with customers. The reviewed scientific and practical publications are distributed according to the industry focus of the research into three groups: wholesale, retail, other industries. According to the areas of study, publications are also systematized into three groups: accounts receivable, settlements with customers, loyalty systems.

Recommendations for improving accounting of settlements with customers, set out in the studied sources are classified in seven areas, including: classification, accounting assessment, documenting and reflection in financial statements, the display in the accounts, turnover indicators and their analysis, implementation of information technology and Internet technology and taxation. On the basis of the research was determined the problematic issues of accounting for settlements with customers in trade, defined five areas that require further research.
\end{abstract}

Keywords: calculations; systematization; settlements with customers; trade; loyalty programs.

\section{REFERENCES (TRANSLATED AND TRANSLITERATED)}

1. Azriliyan, A.N. (Ed.) (1999). Large accounting dictionary. M.: Institute of New Economics. (in Russian)

2. Panteleev, V.P, Snizhko, O.S. (2009). Dictionary of Accountant and Auditor. K.: DP "Inform.-analyst agency." (in Ukrainan)

3. Bezrukyky, P.S. (Ed.). (1999). Accounting. M.: Accounting. (in Russian)

4. Parashutin, N.V., Kozlova, E.P. (1999). Accounting course. M.: Finance. (in Russian) 
5. Parkhomenko, V.M (2010). Payments with buyers and customers: accounting aspect. Economic sciences, 3 (61), 142-145. (in Ukrainian)

6. Ryan, B. (1998). Strategic accounting for the head. M.: Audit, UNITY. (in Russian)

7. Berezina, M.P. (1997). Cashless payments in the Russian economy: Analysis of practice. M.: JSC Consultbankir. (in Russian)

8. Vlasova I.O (2005). Accounting for settlements with debtors and creditors. (Disserted Candidate of Economic Sciences). National Agriculture University, Kiev (in Ukrainian)

9. Tax Code of Ukraine. №755 - VI. (2010). (in Ukrainian)

10. Butinets, F.F. (2005). Accounting and financial accounting. Zhitomir: PE "Ruta". (in Ukrainian)

11. Serdyuk, V.M. (2005). Tax accounting. K.: Center for Educational Literature. (in Ukrainian)

12. Malyshkin, O. (2009). About the status of tax accounting of Ukrainian enterprises. Accounting and Audit, 2, 48-57. (in Ukrainian)

13. Dyakonova, I.I. (2012). Methodological bases of formation of the system of financial management of the bank. Sumy: University Book. (in Ukrainian)

14. Podtserkovny O.P. (1999). Organizational and legal basis of settlement relations in the economic complex of Ukraine (Author's dissertation, Candidate of jurisprudence) of the National Academy of Sciences of Ukraine. In-t of econ-rights. Research, Donetsk. (in Ukrainian)

15. Dzera, O.V., Kuznetsova, N.S. (2003). Civil law of Ukraine. O.D. Dera (Ed.), Money as an object of civil legal relations (book 1). (pp. 153-160). Kyiv: Yurinkom Inter. (in Ukrainian)

16. Akimova, N.S., Toporkova, OV, Evlash, T.O. \& Govorukha O.O. (2016). Accounting and analysis of accounts receivable in the system of management of wholesale trade enterprises. Kharkov: KHDUKHT. (in Ukrainian)

17. Benko, M.M. (2001). Automation of accounting of goods and goods turnover at wholesale trade enterprises. Scientific notes, 9, 94-98. (in Ukrainian)

18. Benko, M.M. (Ed.). (2011). Features of accounting organization at the trade enterprise in the conditions of modern information technologies. Materials V International science-practical conference. Competitiveness in the conditions of globalization: realities, problems and perspectives. Zhitomir: Zhitomir branch of Kiev Institute of Business and Technology. (in Ukrainian)

19. Benko, M.M. (2002). Organization of automated accounting of goods at enterprises of retail trade. Economics: the Problems of Theory and Practice, 154, 7-11. (in Ukrainian)

20. Benko, M.M. (2000). Automation of accounting of retail in the system of enterprise management. Economics: the Problems of Theory and Practice, 46, 21-25. (in Ukrainian)

21. Bogatenko, N. (2007). Discounts: account with seller and buyer. Accounting, 14, 50-52. (in Ukrainian)

22. Boyko, V.I., Pistunov, I.M., Pashkevich, M.S. (2006). Optimization of receivables of the enterprise in the market conditions of Ukraine. Scientific bulletin of the NMU, 7, 99-104. (in Ukrainian).

23. Bulkat, G. (2010). Assessment of receivables under factoring transactions. Economics, 1 (101), 11-16. (in Ukrainian)

24. Yevlash, T.O. (2012). Accounting and analysis of accounts receivable in the system of management of wholesale trade enterprises (Author's abstract of the degree of Candidate of Economic Sciences) Kharkov State Unity of Food and Trade, Kharkov. (in Ukrainian)

25. Zhukov, V.N. (2008). The supplier gave the buyer a discount: what should an accountant know? Accounting, 3, 52-59. (in Ukrainian)

26. Zakrevskaya, O.Y. (2017). Organization of accounting for current trade receivables. Black Sea Economic Studies, 20, 103-106. (in Ukrainian)

27. Kyyashko, O.M. (2011). Accounting and analysis of receivables in the enterprise management system. (Disserted Candidate of Economic Sciences) Kyiv National University of Trade and Economics, Kyiv. (in Ukrainian)

28. Kuzmin, D.L. (2011). Accounting and control of property acquisition process: Theory and methodology. (Author's abstract of the Dissertation of the Candidate of Economic Sciences). Zhitomir State Technical University, Zhitomir. (in Ukrainian)

29. Pedenko, N.N. (2012). Management of receivables. Bulletin of the National Technical University "KhPI", 4, 127-136. (in Ukrainian)

30. Pogorilyak, L.V. (Ed.). (2007). Organization of accounting and analysis of settlements with buyers and customers according to national and international standards. Materials of the final scientific and practical conference of students and postgraduates of the Zakarpatskiy State University. Uzhgorod: ZakDU. (in Ukrainian) 
31. Polatikin, S.O. (2005). Use of information systems in accounting for settlements with buyers and customers. Accounting and Audit: Theory, Practice, Prospects, 5, 188-189. (in Ukrainian).

32. Sakharov, P. O. (2013). The reflection in the accounting the loyalty program with using bonuses. Business Inform, 10, 316-321. (in Ukrainian)

33. Sukhar, I.S. (Ed.) (2009). Analytical and synthetic accounting of settlements with buyers and customers. Materials of the VII International Scientific Conference devoted to the memory of O.S. Borodkin "Development of the system of accounting, analysis and audit in Ukraine: theory, methodology, organization". Kiev: NASOA. (in Ukrainian)

34. Taranenko, IV (2015) Research and assessment of consumers' loyalty in the retail chain in the context of the economic crisis. Taken from: http://www.economy.nayka.com.ua/?op=1\&z=4038 (in Ukrainian)

35. Toporkova, O. V. (2011). Settlements with different debtors in the accounting aspect. Economic strategy and prospects for the development of trade and services, 2 (14), 136-143. (in Ukrainian)

36. Farion, O.O. (2011). Accounts receivable and payable: control and management as a guarantee of successful development. Scientific bulletin of NLTU of Ukraine, 21 (4), 276-282. (in Ukrainian)

37. Fomina, O.V. (2014). Influence of trends in wholesale trade on the development of managerial accounting. Bulletin of the Mechnikov ONU, 19 (2/6), 121-125. (in Ukrainian)

38. Sobolieva-Tereshchenko, O.A., Zharnikova, V.V. (2017). Theoretical and methodological basis for the development of effective loyalty systems. Magazine Manager, 2 (75), 82-91. (in Ukrainian)

39. Sobolieva-Tereshchenko, O.A., Zharnikova, V.V. (2017). Features of accounting settlements with customers in conditions of application of loyalty programs. Scientific bulletin of Uzhgorod University. Series "Economics", 2 (50), 325-332. (in Ukrainian) 